\title{
The Impact of Visual Aids on the Retention of English Word Stress Patterns
}

\author{
Farid Ghaemi ${ }^{1}$, Fahimeh Rafi ${ }^{2 *}$ \\ ${ }^{I}$ Department of English Language Teaching, Karaj Branch, Islamic Azad University, Karaj, Iran \\ ${ }^{2}$ Department of English Language Teaching, Zanjan Branch, Islamic Azad University, Zanjan, Iran \\ Corresponding Author: Fahimeh Rafi, E-mail: fahime.rafi@yahoo.c
}

\section{ARTICLE INFO \\ Article history \\ Received: November 11, 2017 \\ Accepted: January 27, 2018 \\ Published: March 01, 2018 \\ Volume: 7 Issue: 2 \\ Advance access: February 2018}

Conflicts of interest: Non

Funding: None

\begin{abstract}
The present study aimed at comparing the effectiveness of three different techniques on learners' long term memorization of English word stress patterns. After administering a quick placement test, 67 Iranian EFL elementary learners at language institutes were selected to participate in the study. Then they were divided into three groups. Before starting the instruction, a pretest was conducted to classify the participants' abilities on word stress patterns. Then the new techniques were used to teach English word stress patterns. In all three groups, words were printed largely on a piece of paper and the syllables were clearly specified by dots. In group 'A', pronunciation and stress pattern of new words were taught aurally through the repetition of the words. In group 'B', all the procedure was exactly similar to that of group 'A', the only difference was that the stressed syllables were printed in bold. In group ' $\mathrm{C}$ ', all the procedure was exactly similar to that of group 'B', except that the stressed syllables were not only printed in bold, but also introduced by teacher's hand gesture. After two weeks, a delayed posttest was conducted to check long term memorization of the word stress patterns. The results of the study indicated that there was a significant difference between pretest and delayed posttest in all three groups. But the most meaningful difference belonged to group ' $\mathrm{C}$ '. That is, the participants in the third group (gesture group) outperformed those in the other groups. Finally, some implications and suggestions provided for further research.
\end{abstract}

Key words: EFL, Bold, Gesture, Memorization, Syllable, Word Stress Pattern

\section{INTRODUCTION}

Those who want to learn English language usually encounter a lot of difficulties in pronunciation, mainly because of lack of stress knowledge of English language. English pronunciation has various components such as sounds, stress, and variations in pitch. Using these components is not just to complete meaning, but to create meaning (Morley, 1999). Using pronunciation components can also be crucial for English communication; because it helps the learners not only understand the speakers but also make themselves understood. Pourhossein Gilakjani and Ahmadi (2011) stated that if we are going to alter the way learners pronounce words, we should change the way they think about component sounds of those words. This goes not just for individual sounds, but for other elements of speech, such as syllables, stress patterns, and rhythm. Moreover, there are many researchers and teachers who believe in the importance of using visual aids, such as gestures, in language learning and teaching. There is convincing evidence that act of gesturing can increase learning.

There is a great difference in the nature of English and Persian word stress patterns, and this is one of the major reasons that Iranian EFL learners usually mispronounce
English words. Therefore, it seems crucial to teach English stress patterns to Iranian EFL learners in order to improve their pronunciation which can finally lead to more successful communication.

\section{Vocabulary, Pronunciation and Communication}

Learning vocabulary is an essential part of language learning. Without the knowledge of vocabulary, none of the language skills can be learned or taught. Vocabulary is a medium which conveys meaning. Learning to comprehend and express the meaning is crucial in language learning (Shahabi and Shahrokhi, 2016).

Thornbury (2004) also argued that vocabulary is mainly a matter of remembering. Thus learning vocabularies is important, but what is more important is the matter of keeping vocabularies in mind. There are different strategies or techniques that help students to acquire or memorize new vocabularies. Teachers should be aware of these techniques in order to be able to help their students learn the words easily and quickly. There are different definitions for 'memorizing'. Richards and Schmidt (2010) defined memorizing as "the process of establishing information, etc. in memory. 
The term memorizing usually refers to conscious processes" (p. 359); in this definition, the word 'conscious' is very important, it shows that people consciously use their memorization (Duong and Nguyen, 2006).

Teaching vocabulary is always accompanied by teaching pronunciation. English pronunciation is one of the most difficult skills for teachers to teach and learners to learn. Pronunciation is more than just pronouncing individual sounds in isolation. Teaching pronunciation involves a variety of challenges (Gilbert, 2008).

Is it the goal of pronunciation instruction to imitate exactly the way native speakers pronounce? Nowadays, there are a lot of scholars who believe that intelligible, not native-like, pronunciation is the purpose of pronunciation instruction (Pourhosein Gilakjani, 2016).

Pourhosein Gilakjani (2012) believed that good pronunciation leads to learning while bad pronunciation brings about great difficulties in language learning. Teaching pronunciation is necessary for oral communication and also communicative competence (Hismanoglu, 2006). Harmer (2001) believed that the most important purpose of teaching and learning a language is to enable learners to communicate in that language. Native speakers can understand what people say, despite their grammatical errors, if they use correct pronunciation. This shows the importance of teaching and learning pronunciation in language classes. Garrigues (1999) also stated that the basis for effective spoken communication is good pronunciation, because it can primarily affect accuracy and comprehension.

\section{The Importance of Teaching Stress Patterns}

Students who attempt to learn English language usually encounter a lot of difficulties in pronunciation, mainly because of lack of stress knowledge of English language. Harmer (2007) argued that stress is used to describe the point in a word or phrase where pitch changes, vowels are lengthened and volume is increased (Cited in Yangklang, 2013).

English pronunciation has different components such as sounds, stress, and variations in pitch. Sound system emphasizes the crucial importance of suprasegmental features, such as stress, rhythm, and intonation. In fact, In English, word stress must be assigned to over $90 \%$ of all words to be regarded as correct in terms of pronunciation and their syntactic, semantic aspects (Arciuli, Monaghan, \& Seva, 2010, as cited in Heidari-Shahreza \& Moinzadeh, 2012). This shows the importance of correct placement of word-level stress in EFL speech training.

Teachers should pay more attention to different aspects of phonology. They must emphasize teaching pronunciation and particularly stress. Ratchie and Bhatia (2008) stated it is really important to integrate pronunciation into elementary classes from the very beginning in order to avoid the risk of fossilization and stabilization of wrong pronunciation. When children's ability in language develops, teachers must make them familiar with phonemes and their stress patterns. As Field (2005) believed that teaching word stress can improve students' pronunciation. Curtin (2010) argued that even young children can memorize the stress information about the words, that is, the position in which the stressed syllable occurs. Therefore, making students aware of stress (and also intonation) is necessary for improving pronunciation (Yangklang, 2013).

Zhang and Yin (2009) believed that correct stress and intonation can improve English communication ability. Small (2005) also indicated that language learners sound 'foreign' when they speak the new language with their first language stress pattern. Therefore, teachers should make students familiar with syllables, stress patterns, and rhythm, and try to practice them in their classes. In such a way, learners can understand what is important to focus on.

\section{Gesture as a Tool for Teaching and Learning}

Gesture is the movement of head, face, hand, or body that conveys meaning. People in all languages usually use gesture when they speak. Gesture can be used as a tool for thinking and learning (Goldin-Meadow, 2010). There are many studies that show the positive influence of gestures in second language acquisition. Tellier (2005) investigated the effectiveness of gestures on short-term memorization of new words. Tellier compared the impact of watching versus watching and reproducing gestures. Tellier reported that participants who had reproduced gestures could memorize the words better than those who had just looked at them. Moreover, Tellier (2008) examined the impact of gesture on second language vocabulary memorization. Tellier compared two groups of young children; the first group was taught words with pictures and the second group with accompanying gestures. As it was expected, the result was in favor of the gesture group. Tellier concluded that gestures and especially reproducing gestures can have great effect in vocabulary memorization. Moreno and Mayer (2000) also supported such an idea by arguing that multimedia learning can be more influential because of conveying both auditory and visual information.

Nearly all teachers believe in the importance of gesture in language learning and teaching. " Gestures allow for a fuller picture of the processes of language acquisition in which the learner's individual cognition is situated in a social, interactive context" (Gullberg, de Bot, \& Volterra, 2008, p. 4). Goldin-Meadow (2010) also stated that gesture can play a role in learning in two ways: first, by affecting the kind of communicative input the learner receives; and second, by changing the learner's cognitive state. Most of the learners at the elementary levels will need gesture alongside verbal communication to enable them deal with what they say or hear (Bosiwah and Esi Bronteng, 2015). Therefore, there are many situations in which using auditory stimuli do not suffice, and visual stimuli seem to be necessar

According to Goldin-Meadow and Alibali (2013), gestures that speakers produce can: 1) reflect speakers' thoughts, 2) change speakers' thoughts, and 3) provide building blocks that can be used to construct a language. Broaders, Cook, Mitchell \& Goldin-Meadow (2007) also indicated that encouraging learners to gesture may serve to activate their implicit knowledge, and making them particularly receptive to instruction (Cited in Goldin-Meadow and Alibali, 2013). 
That is, if learners look at teacher's gesture, they can learn better; but the optimal situation is the one in which students not only look at teacher's gesture, but also reproduce it as well.

In the present study, we are going to see how gestures and also reproduction of gestures influence memorization

\section{RESEARCH QUESTIONS}

The questions which are posed in this study are as follows:

1. Is there any significant difference between word stress pattern retention by adult elementary EFL learners who are taught through presenting the stressed syllables in bold and those who are not?

2. Is there any significant difference between word stress pattern retention by adult elementary EFL learners who are presented the stressed syllables through gesture and those who are not?

\section{METHODOLOGY}

\section{Participants}

The participants of this study included 67 female adult learners within the age range of 36-45 studying at private language institutes in Zanjan. They were all bilingual speakers who could speak Persian and Turkish perfectly.

At the beginning, 83 adult learners took part in the quick placement test through which 67 participants who were at the elementary level were selected and then divided into three groups. The size of the participants in groups ' $A$ ', ' $B$ ' and ' $C$ ' was 21,22 and 24 , respectively.

\section{Instruments}

\section{Placement test}

A quick placement test was used to ascertain the learners' level of language proficienc . 83 adult learners took part in the placement test and 67 were chosen as elementary learners and divided into three groups.

\section{Pretest}

A list of 30 two- and three- syllable words was selected from students' textbook. The syllables in each word were specified by dots and the participants in each group had to underline the stressed syllables. Then, the papers were collected and scored, and the mean score and standard deviation for each group were calculated.

Due to the special form of the pretest (underline form), the test was given to four university lecturers to check its validity.

\section{Delayed Posttest}

The questions and their forms in the delayed posttest were exactly the same as the ones in the pretest. The participants had to take part in the delayed posttest exam which was administered two weeks after the last session of the treatment.
There were three groups in the study and the delayed posttest questions for all of them were the same. The researchers wanted to see which technique was more useful and infl ential in long-term memorization of the word stress patterns.

\section{Procedure}

First, a placement test was administered to 83 female adult participants, 67 of whom were chosen as elementary learners and randomly divided into three groups. The groups were named as ' $A$ ', ' $B$ ' and ' $C$ '. The size of the participants in groups 'A', 'B' and ' $\mathrm{C}$ ' was 21,22 and 24 , respectively.

Then, the selected participants took part in a pretest. The pretest consisted of 30 words which were chosen from the students' textbook. The syllables in each word were specified by dots, and the participants were just supposed to underline the stressed syllables. After administering the pretest, the papers were collected and scored. Then, the mean score and standard deviation for each group were calculated.

Each groups met twice a week at exactly the same time in the morning for five sessions. At the beginning of the first session, in all three classes, the teacher provided the students with a brief explanation of the syllables and stressed patterns in English.

Then, the following procedure was carried out in different groups:

1. In group ' $A$ ', pronunciation and stress pattern of new words were taught aurally through the repetition of the words. It is worth mentioning that each new word was printed largely on a piece of paper and the syllables were clearly specifie by dots. Each word was pronounced five times by the teacher and each time students were to repeat it, chorally. Then, the teacher asked the students to repeat each of the words individually, as well. The teacher pronounced the words in a way that learners could guess on which syllable the stress falls, and students tried to reproduce the same stress pattern.

2. In group ' $\mathrm{B}$ ', all the procedure was exactly similar to that of group 'A'. The only difference was that the stressed syllables were printed in bold. That is, students could not only listen to the teacher's pronunciation for the stressed syllables, but also recognize them by just looking at the words.

3. In group ' $\mathrm{C}$ ', all the procedure was exactly similar to that of group ' $\mathrm{B}$ '. The only difference was that the stressed syllables were not only printed in bold, but also introduced by teacher's hand gesture. The hand gesture was in a way that for each unstressed syllable the teacher moved her hand forward horizontally, but when she came to the stressed syllables, she moved her hand upward to show that learners should raise their voice. For each repetition, teacher used hand gesture and made the students reproduce it, as well. Table 1 shows how the word stress patterns were taught to each group.

The study lasted for five sessions. There were two sessions every week. In each session ten similar new words were taught to the three groups, but through different techniques.

The participants in all three groups had to take part in delayed posttest exam which was administered two weeks after 
the last session of the treatment. The questions and their forms in the delayed posttest were exactly the same as the ones in the pretest. It is worth mentioning that none of the words or syllables in delayed posttest was presented in bold. In scoring, each correct answer received one positive point, and there was no negative point for wrong answers. The researchers were willing to see if there were any differences in the retention of word stress patterns comparing the three groups.

\section{RESULTS}

After administering the pretest and delayed posttest, participants' papers, in the three groups, were collected, scored, and compared in order to see which technique was more influential in memorizing the word stress patterns. To test the normality of the scores distribution, the Kolmogorov-Smirnov test was conducted.

Table 2 clearly proves the normality of the scores in pretest and delayed posttest ( $p$-value $>0.05$ ). The scores of the

Table 1. The way each group was instructed

\begin{tabular}{|c|c|}
\hline GA & $\begin{array}{l}\text { Watching (no syllables printed in bold), listening, } \\
\text { repeating }\end{array}$ \\
\hline GB & $\begin{array}{l}\text { Watching (stressed syllables printed in bold), listening, } \\
\text { repeating }\end{array}$ \\
\hline $\mathrm{GC}$ & $\begin{array}{l}\text { Watching (stressed syllables printed in bold), listening, } \\
\text { hand gesturing }\end{array}$ \\
\hline
\end{tabular}

Table 2. Results on test of normality

\begin{tabular}{llcl}
\hline Groups & Tests & Sig & Results \\
\hline A & Pretest & 0.2 & Normal distribution \\
A & Posttes & 0.250 & Normal distribution \\
B & Pretest & 0.129 & Normal distribution \\
B & Posttest & 0.2 & Normal distribution \\
C & Pretest & 0.263 & Normal distribution \\
C & Posttest & 0.411 & Normal distribution \\
\hline
\end{tabular}

three groups on the pretest were descriptively analyzed and presented in Tables 3 and 4.

As Table 3 represents, the scores of the three groups on pretest have similar ranges of dispersion and mean scores. That is, the participants' scores on pretest were not much different. Table 4 shows p-value $>0.05(0.349>0.05)$ which proves that there is not any significant difference among the mean scores of the three groups.

Table 5 also represents the scores of the three groups on delayed posttest.

Based on the data presented in Table 5, the researchers concluded that the performance of all three groups on delayed posttest was much better than that of pretest. However, the mean score of group „, $\mathrm{A}^{\text {ee }}$ is much lower than that of groups , $\mathrm{B}^{\mathrm{Ce}}$ and, $\mathrm{C}^{\mathrm{ec}}$ on delayed posttest. That is, participants for whom the stressed syllables were presented in bold and those for whom gesture was also applied could memorize the stressed syllables much better than the first group

The one-way ANOVA results $(\mathrm{F}(2,64)=70.486$, $\mathrm{P}<.05)$ indicated that there is a significant difference among the mean scores of the three groups. This shows the positive impact of the techniques the researchers used in teaching word stress patterns in groups ' $\mathrm{B}$ ' and ' $\mathrm{C}$ '. And the highest mean score on delayed posttest belongs to group ' $\mathrm{C}$ ', to which the word stress patterns were instructed via gesture.

Although the F-value of 70.486 indicated significant differences between the means of the three groups, the post-hoc Scheffe's tests (Table 7) should be run to compare the means two by two.

As Table 7 suggests, comparing the mean scores of groups two by two, we can see a significant difference between the mean scores, too. Table 8 also shows the comparison between the mean scores of pretest and delayed posttest in each group.

In all three groups, there is difference between pretest and delayed posttest. But this difference in groups ' $\mathrm{B}$ ' and ' $\mathrm{C}$ ' is more significant. And the most meaningful difference belongs to group ' $\mathrm{C}$ '.

Table 3. Descriptive statistics for the three groups on pretest

\begin{tabular}{|c|c|c|c|c|c|c|c|c|}
\hline \multirow[t]{2}{*}{ Groups } & \multirow[t]{2}{*}{$\mathbf{N}$} & \multirow[t]{2}{*}{ Mean } & \multirow[t]{2}{*}{ Standard deviation } & \multirow[t]{2}{*}{ Standard error } & \multicolumn{2}{|c|}{$\begin{array}{l}95 \% \text { confidence } \\
\text { interval for mean }\end{array}$} & \multirow[t]{2}{*}{ Minimum } & \multirow[t]{2}{*}{ Maximum } \\
\hline & & & & & $\begin{array}{l}\text { Lower } \\
\text { bound }\end{array}$ & $\begin{array}{l}\text { Upper } \\
\text { bound }\end{array}$ & & \\
\hline $\mathrm{A}$ & 21 & 12.0000 & 2.23607 & 0.48795 & 10.9822 & 13.0178 & 8.00 & 15.00 \\
\hline B & 22 & 11.4545 & 1.18431 & 0.25250 & 10.9295 & 11.9796 & 10.00 & 13.00 \\
\hline $\mathrm{C}$ & 24 & 11.2500 & 1.72576 & 0.35227 & 10.5213 & 11.9787 & 9.00 & 14.00 \\
\hline Total & 67 & 11.5522 & 1.76054 & 0.21508 & 11.1228 & 11.9817 & 8.00 & 15.00 \\
\hline
\end{tabular}

Table 4. One-way ANOVA for the three groups on pretest

\begin{tabular}{lccccc}
\hline & Sum of squares & df & Mean square & F & Sig. \\
\hline Between groups & 6.613 & 2 & 3.306 & 1.069 & 0.349 \\
Within groups & 197.955 & 64 & 3.093 & \\
Total & 204.567 & 66 & & \\
\hline
\end{tabular}


Table 5. Descriptive statistics for the three groups on delayed posttest

\begin{tabular}{|c|c|c|c|c|c|c|c|c|}
\hline \multirow[t]{2}{*}{ Groups } & \multirow[t]{2}{*}{$\mathbf{N}$} & \multirow[t]{2}{*}{ Mean } & \multirow[t]{2}{*}{ Standardd deviation } & \multirow[t]{2}{*}{ Standard error } & \multicolumn{2}{|c|}{$\begin{array}{l}95 \% \text { confidence } \\
\text { interval for mean }\end{array}$} & \multirow[t]{2}{*}{ Minimum } & \multirow[t]{2}{*}{ Maximum } \\
\hline & & & & & $\begin{array}{l}\text { Lower } \\
\text { bound }\end{array}$ & $\begin{array}{l}\text { Upper } \\
\text { bound }\end{array}$ & & \\
\hline A & 21 & 15.1429 & 2.53546 & 0.55328 & 13.9887 & 16.2970 & 11.00 & 19.00 \\
\hline B & 22 & 22.0455 & 2.39995 & 0.51167 & 20.9814 & 23.1095 & 18.00 & 26.00 \\
\hline $\mathrm{C}$ & 24 & 24.1250 & 2.87890 & 0.58765 & 22.9093 & 25.3407 & 20.00 & 29.00 \\
\hline Total & 67 & 20.6269 & 4.62154 & 0.56461 & 19.4996 & 21.7541 & 11.00 & 29.00 \\
\hline
\end{tabular}

Table 6. One-way ANOVA for the three groups on delayed posttest

\begin{tabular}{lccccc}
\hline & Sum of squares & df & Mean square & F & Sig. \\
\hline Between groups & 969.521 & 2 & 484.760 & 70.486 & \\
Within groups & 440.151 & 64 & 6.877 & \\
Total & 1409.672 & 66 & & \\
\hline
\end{tabular}

Table 7. Multiple comparison among the three groups' delayed posttest

\begin{tabular}{llccccc}
\hline (I) code & $(J)$ code & Mean difference $(\mathbf{I}-J)$ & Standard error & Sig. & \multicolumn{2}{c}{ 95\% confidence interval } \\
\cline { 5 - 7 } & & & & & Lower bound & Upper bound \\
\hline A & B & $-6.90260^{*}$ & 0.80006 & 0.000 & -8.5009 & -5.3043 \\
& C & $-8.98214^{*}$ & 0.78361 & 0.000 & -10.5476 & -7.4167 \\
B & A & $6.90260^{*}$ & 0.80006 & 0.000 & 5.3043 & 8.5009 \\
& C & $-2.07955^{*}$ & 0.77406 & 0.009 & -3.6259 & -0.5332 \\
C & A & $8.98214^{*}$ & 0.78361 & 0.000 & 7.4167 & 10.5476 \\
& B & $2.07955^{*}$ & 0.77406 & 0.009 & 0.5332 & 3.6259 \\
\hline
\end{tabular}

*The mean difference is significant at the 0.05 level.

Table 8. Paired sample statistics

\begin{tabular}{ccccc}
\hline Groups & Mean & $\mathbf{N}$ & $\begin{array}{c}\text { Standard } \\
\text { deviation }\end{array}$ & $\begin{array}{c}\text { Standard error } \\
\text { mean }\end{array}$ \\
\hline A & & & & \\
$\quad$ Pair 1 & & & & \\
$\quad$ Pre & 12.0000 & 21 & 2.23607 & 0.48795 \\
$\quad$ Post & 15.1429 & 21 & 2.53546 & 0.55328 \\
B & & & & \\
Pair 1 & & & & \\
$\quad$ Pre & 11.4545 & 22 & 1.18431 & 0.25250 \\
$\quad$ Post & 22.0455 & 22 & 2.39995 & 0.51167 \\
C & & & & \\
Pair 1 & & & & \\
$\quad$ Pre & 11.2500 & 24 & 1.72576 & 0.35227 \\
$\quad$ Post & 24.1250 & 24 & 2.87890 & 0.58765 \\
\hline
\end{tabular}

Table 9 clearly shows that there is a significant difference between the mean scores of pretest and delayed posttest in the three groups $(p<0.05)$. In groups ' $B$ ' and ' $C$ ', there is a meaningful and statistically significant difference between their mean scores of pretest and delayed posttest.

On the other hand, comparing the mean scores of pretest and delayed posttest in groups ' $\mathrm{B}$ ' and ' $\mathrm{C}$ ', we notice greater difference in group ' $\mathrm{C}$ ' than group ' $\mathrm{B}$ '. It shows that students to whom word stress patterns were taught by using gesture were more successful in delayed posttest exam than those for whom the word stress patterns were presented in bold.

To sum up, the findings in this study confirms that using bold prints and gestures are two influential techniques in memorizing English word stress patterns, although gesture is a more influential technique than bold print is

\section{DISCUSSION}

The current study was designed to investigate the impact of visual aids on long-term memorization of word stress patterns in English. The research questions in this study focused on the influence of using visual aids in learning English word stress patterns. The results proved the strong impact of gesture on long-term memorization of word stress patterns. Several studies have been conducted on gestures or visual aids, but there are a few studies on the impact of visual aids on the memorization of word stress patterns.

The result of the present study was consistent with previous studies (Bosiwah \& Esi Bronteng, 2015; Goldin-Meadow \& Alibali, 2013; Abbasi Mesrabadi \&Rahmany, 2012; Goldin-Meadow, 2010; Broaders, et al, 2007; Gullberg, et al, 2008; Cook \& Goldin- Meadow, 2006) which have proved that gesture can encourage and facilitate learning. 
Table 9. Paired samples test

\begin{tabular}{|c|c|c|c|c|c|c|c|c|}
\hline \multirow[t]{3}{*}{ Groups } & \multicolumn{5}{|c|}{ Paired differences } & \multirow[t]{3}{*}{$\mathbf{t}$} & \multirow[t]{3}{*}{ Df } & \multirow[t]{3}{*}{ Sig. (2-tailed) } \\
\hline & \multirow[t]{2}{*}{ Mean } & \multirow[t]{2}{*}{$\begin{array}{l}\text { Standard } \\
\text { deviation }\end{array}$} & \multirow[t]{2}{*}{$\begin{array}{l}\text { Standard } \\
\text { error mean }\end{array}$} & \multicolumn{2}{|c|}{$\begin{array}{c}95 \% \text { confidence interval } \\
\text { of the difference }\end{array}$} & & & \\
\hline & & & & Lower & Upper & & & \\
\hline \multicolumn{9}{|l|}{ A } \\
\hline \multicolumn{9}{|l|}{ Pair 1} \\
\hline Pre - Post & -3.14286 & 1.01419 & 0.22131 & -3.60451 & -2.68121 & -14.201 & 20 & 0.000 \\
\hline \multicolumn{9}{|l|}{ B } \\
\hline \multicolumn{9}{|l|}{ Pair 1} \\
\hline Pre - Post & -10.59091 & 2.28158 & 0.48644 & -11.60251 & -9.57931 & -21.772 & 21 & 0.000 \\
\hline \multicolumn{9}{|l|}{$\mathrm{C}$} \\
\hline \multicolumn{9}{|l|}{ Pair 1} \\
\hline Pre - Post & -12.87500 & 2.62616 & 0.53606 & -13.98393 & -11.76607 & -24.018 & 23 & 0.000 \\
\hline
\end{tabular}

In 2016, Shahabi and Shahrokhi investigated the effectiveness of gestures and facial expressions on teaching vocabulary to Iranian elementary EFL learners. The results indicated that gesture and facial expressions can play a significant role in vocabulary acquisition. Moreover, the finding in this study was in line with Tellier's (2005), and Moreno and Mayer's (2000) which have shown that gestures can have positive role in not only comprehension but also memorization. In accordance with the current study Marion Tellier (2008) also claimed that gestures and especially reproducing gestures can leave a rich trace in memory.

Concerning the use of visual aids in teaching, as Macwan (2015) claimed that using visual aids in ESL classroom is a sort of challenge to teach learners because it demands attention and interest, this study depicted that visual aids are sine qua non for vocabulary retention. Moreover, Dilshodovna (2014) supported the idea and stated that teaching without visual aids cannot be imagined; because visual aids are considered as main teaching strategies that can assist learners to realize the deep meaning of a topic, and strengthen what students have learnt. The studies of Ozaslan \& Maden (2013), Yunus, Salehi, \& John (2013), and Sherman (2003) on the use of visual aids were also in accordance with the present study, as they have proved the positive role of visual aids in teaching and learning. In fact, the finding of the current study extends those of previous studies in that it supports the assumption that visual aids (especially gestures) could be utilized to assist learning.

\section{CONCLUSION}

The primary aim of this research was to investigate the impact of visual aids on long-term memorization of word stress patterns in English. Three groups of EFL learners took part in the study. They were all taught the stress patterns of some words. In all three groups the participants were able to see the words, the syllables of which were specified by dots. The pronunciation and stress pattern of words in the first group were taught aurally. In the second group all the procedure was exactly similar to that of the first group except that the stressed syllables were printed in bold. In the third group, all the procedure was exactly similar to that of the second group except that the stressed syllables were not only printed in bold, but also introduced by teacher's hand gesture. The results were in favor of the third group. That is, combination of bold print and hand gesture can have significant effect on long-term memorization of English word stress patterns. Therefore, it is necessary for the English teachers to pay attention to the importance of using visual aids, especially gestures, in teaching pronunciation and word stress patterns.

\section{SUGGESTIONS FOR FURTHER RESEARCH}

Further researches can be done to answer some issues that are still not being investigated in this study. First, there were 67 participants in the study; other studies can be done with greater number of participants. Second, the participants of this study were adult learners; further studies can be done with children or teenagers. Third, in the current study longterm memorization of word stress patterns was investigated; further studies can be done on short-term memorization. Fourth, the participants in the study were females; other studies can be done with male participants. Fifth, the participants in the current study were at elementary level; further studies can be done with intermediate or advanced level participants.

\section{REFERENCES}

Abbasi Mesrabadi, P. \& Rahmany, R. (2012). Learning English auxiliary modal verbs by Iranian children. Journal of Teaching English Language Studies, 1(3), 57-68.

Arciuli, J., Monaghan, P. \& Seva, N. (2010). Learning to assign lexical stress during reading aloud: Corpus, behavioral, and computational investigations. Journal of Memory and Language, 63(2), 180-196.

Bosiwah, L. \& Bronteng, J. E. (2015). The power of meaningful gestures in teaching and learning literacy in early childhood education centres in the Cape Coast Metropolis. International Journal of Elementary Education, 4(3), 46-55. Doi:10.11648/j.ijeedu.20150403.12.

Broaders, S. C., Cook, S. W., Mitchell, Z., Gol- 
din-Meadow, S. (2007). Making children gesture brings out implicit knowledge and leads to learning. Journal of Experimental Psychology: General, 136, 539-50.

Cook, S. W., \& Goldin-Meadow, S. (2006). The role of gesture in learning: Do children use their hands to change their minds? Journal of Cognition and Development, $7(2), 211-232$.

Curtin, S. (2010). Young infants encode lexical stress in newly encountered words. Journal of Experimental Child Psychology, 105(4), 376-38.

Dilshodovna, D. N. (2014). Using visual aids in teaching English. Modern Pedagogy,5. [Electronic journal]. URL: http://pedagogika.snauka.ru/en/2014/05/2306

Duong, T. H. O. \& Nguyen, T. H. (2006). memorization and EFL students' strategies at university level in Vietnam. TESL-EJ, 10(2), 1-21.

Field, J. (2005). Intelligibility and the listener: The role of lexical stress. TESOL Quarterly, 39(3), 399-423.

Garrigues, S. (1999). Overcoming pronunciation problems of English teachers in Asia. [Online] Available: http:// asianbridges.com/pac2/presentations/garrigues.html.

Gilbert, J. B. (2008). Teaching pronunciation: Using the prosody pyramid. Cambridge: Cambridge University Press.

Goldin-Meadow, S. (2010). When gesture does and does not promote learning. Lang Cogn, 2(1), 1-19.

Goldin-Meadow, S. \& Alibali, M. W. (2013). Gesture's role in speaking, learning, and creating language. The Annual Review of Psychology, 64, 257-83.

Gullberg, M., de Bot, K., \& Volterra, V. (2008). Gestures and some key issues in the study of language development. Gesture, 8(2), 149-179. DOI: 10.1075/gest.8.2.03gul.

Harmer, J. (2001). The practice of English language teaching. London: Longman.

Heidari-Shahreza, M. A. \& Moinzadeh, A. (2012). Teaching word stress patterns of English using a musically-simulated technique. GEMA Online Journal of Language Studies, 12(2),521-37.

Hismanoglu, M. (2006). Current perspectives on pronunciation learning and teaching. Journal of Language and Linguistic Studies, 2(1), 101-110.

Macwan, H. J. (2015). Using visual aids as authentic material in ESL classrooms. Research Journal of English Language and Literature (RJELAL), 3(1), 91-96.

Moreno, Roxanna \& Richard E. Mayer (2000). A learner-centered approach to multimedia explanations: Deriving instructional design principles from cognitive theory. Interactive Multimedia Electronic Journal of Computer Enhanced Learning, 2 (2).
Morley, J. (1999). Trends in speech/pronunciation instructional theory and practice. TESOL Matters, August/September.

Ozaslan, E.N., \&Maden, Z. (2013). The use of PowerPoint presentation in the department of foreign language education at Middle East technical university. Middle Eastern \& African Journal of Educational Research, 2, 38-45.

Pourhosein Gilakjani, A., \& Ahmadi, M. R. (2011). Why is pronunciation so difficult to learn? English Language Teaching, 4(3), 74-83.

Pourhosein Gilakjani, A. (2012). A study of factors affecting EFL learners' English pronunciation learning and the strategies for instruction. International Journal of $\mathrm{Hu}$ manities and Social Science, 2(3), 119-128.

Pourhosein Gilakjani, A. (2016). English pronunciation: A literature review. Journal of Research in English Education, 1(1), 1-6.

Ratchie C.\& Bhatia K., (2008). Phycholinguistics. In B. Spolsky and F,M. Hult (eds.), The handbook of educational linguistics, 27, 184-202.

Richards, J. C. \& Schmidt, R. (2010). Dictionary of language teaching and applied linguistics. (4th ed.). UK: Pearson Education Limited.

Shahabi, H. \& Shahrokhi, M. (2016). Contributory role of the gestures and facial expressions in teaching concrete vocabulary items to Iranian elementary EFL learners. Journal of Applied Linguistics and Language Research, 3(5), pp. 160-176.

Sherman, J. (2003). Using authentic video in the language classroom. Cambridge: CUP. The Internet TESL Journal, 10 (10).

Tellier Marion (2008). The effect of gestures on second language memorization by young children. Gesture, John Benjamins Publishing, 8 (2), 219-235.

Thornbury, (2004) Scott. How to teach vocabulary. Essex: Pearson Education Limited.

Yangklang, W. (2013). Improving English stress and intonation pronunciation of the first year students of Nakhon Ratchasima Rajabhat university through an E-learning. Procedia-Social and Behavioral Sciences, 91, 444-452.

Yunus, M. M., Salehi, H., \& John, S. A. (2013). Using visual aids as a motivational tool in enhancing students' interest in reading literary text. Recent Advances in Educational Technologies, 114-17.

Zhang, F. \& Yin, P. (2009). A study of pronunciation problems of English learners in China. Asian Social Science, 5(6), 141-146. 